\title{
Supercritical Extraction of Cobia (Rachycentron canadum) Liver Oil as a New Source of Squalene
}

\author{
Débora Nascimento e Santos, Eliane Hissae Takahashi, \\ Alessandra Barros Verde, Alessandra Lopes de Oliveira*
}

Food Engineering Department, Faculty of Animal Science and Food Engineering, University of Sao Paulo, Pirassununga, Brazil

\begin{abstract}
Cobia is a fish cultivated worldwide and there are few studies on the potential of their waste, such as the liver, it's rich in oil and active compounds. The objective of this study was to extract cobia liver oil (CLO) using supercritical $\mathrm{CO}_{2}$ under moderate temperature conditions $\left(50,60\right.$ and $\left.70{ }^{\circ} \mathrm{C}, 250 \mathrm{bar}\right)$ and characterize the oil (physico-chemical analysis, fatty acids profile and squalene content). The results showed that CLO is rich in MUFA and presented squalene, suggesting that this matrix can be applied in the production of high nutritional value oil.
\end{abstract}

Keywords Liver fish oil, Cobia, Supercritical extraction, Omega 3, Squalene

\section{Introduction}

Cobia, Canadum Rachycentron, is a marine fish native to Brazil and found in tropical and subtropical seas. In captivity, this fish presents a high growth rate with low incidence of disease and produces high-quality meat $[1,2]$. Because of these attributes, this species has been widely used in aquaculture in some countries in Asia and the Pacific region, generating a product of great economic value [3]. In Brazil, the production of cobia in captivity was initiated in 2006, and it continues in expansion due to encouragement from the Fishery Ministry and the private sector [4]. The cobia growing in captivity generated stimulus for studies about feeding and management techniques for growth efficiency.

The world production of fish, including fishing and fish farming, was 158 million tons in 2012. Out of this total, 136.2 million tons ( $86 \%$ of total production) were used for human consumption, and the remaining 14\% (21.7 million tons) was used for non-food purposes such as fishmeal and fish oil production [5]. Fish oil extraction can be classified into physical, chemical, and biological processes. The chemical extraction, realised with organic solvents, is a process well established. However, the use of toxic solvents can result in protein denaturation and loss of functional properties $[6,7]$. In this context, supercritical fluid extraction is a potential alternative for the many advantages that it presents in relation to other methods.

Supercritical fluid extraction using $\mathrm{CO}_{2}$ as a solvent can be applied to obtain fish oil rich in unsaturated fatty acids at

* Corresponding author:

alelopes@usp.br (Alessandra Lopes de Oliveira)

Published online at http://journal.sapub.org/fph

Copyright (C) 2016 Scientific \& Academic Publishing. All Rights Reserved low temperatures. Supercritical $\mathrm{CO}_{2}$ extraction produces no oxygen in the process, which is responsible for the oxidation of fatty acids. The supercritical $\mathrm{CO}_{2}$ density can be easily changed with temperature and pressure alteration, which modifies the solvating power of the solvent. Another known characteristic is the low toxicity of $\mathrm{CO}_{2}$ that is recognised as safe (GRAS) and still produces clean waste extraction and solvent-free extracts $[8,9]$.

The first studies of the application of supercritical $\mathrm{CO}_{2}$ extraction in fish oils were conducted in the 1950s. They studied the phase equilibrium data and compounds of the fish oils obtained by supercritical $\mathrm{CO}_{2}$ and other organic solvents [10]. Some studies have shown the fractions purification of substances such as ethyl esters, eicosapentaenoic acid (EPA) and docosahexaenoic acid (DHA) [11], acid esters of fish oils [12], and contaminants [13]. In recent studies, supercritical extraction has been applied for new fish species or by-products [14] or as an extraction method combined with other processes such as molecular distillation [15] in order to optimise the fractionation of compounds with biological activity such as alkylglycerols and squalene.

The objective of this research was to obtain cobia liver oil (CLO) using supercritical extraction in different operational conditions in order to characterise this oil by determining physico-chemical parameters and the fatty acid profile and by investigating the presence of bioactive compounds such as squalene. In addition to the study of clean technology to extract CLO, this study aimed to use waste from the fishing industry, such as raw material, for the production of oil with active properties.

\section{Materials and Methods}

\subsection{Materials and Sample Characterisation}


Frozen cobia (Canadum Rachycentron) liver samples were provided by a commercial marine farm located in Ubatuba/Sao Paulo, BR. The livers were cut into small pieces and freeze-dried for $24 \mathrm{~h}$ (LC-1500 Terroni, Sao Carlos, BR). After lyophilisation, they were stored at $-20^{\circ} \mathrm{C}$ until the supercritical extraction. An aliquot of the liver samples was used for chemical composition analysis. Moisture, ashes, lipids, fibre, protein, and carbohydrate assays were performed in triplicate, in accordance with the standards of the Institute Adolfo Lutz (IAL) [16].

\subsection{Supercritical $\mathrm{CO}_{2}$ Extraction of Cobia Liver Oil}

Lyophilised liver samples (15 g) cut into non-uniform small pieces were placed in a fixed bed extractor with 300 $\mathrm{cm}^{3}$, which was completed with glass beads (with diameter of $5 \mathrm{~mm}$ ). The equipment used is schematised in Fig. 1 (Thar SFC, Pittsburgh, USA). During operation of the equipment, $\mathrm{CO}_{2}$ (1) (99.9\% Oxinitro, Pirassununga, BR) leaves the cylinder and follows to be cooled in a thermostatically controlled bath (2) to $-2.3^{\circ} \mathrm{C}$ (Thermo Scientific, Walthan, USA). Liquid $\mathrm{CO}_{2}$ is pumped with an HPLC pump (3) (Thar P54, Pittsburgh, USA) to a heat exchanger (4), where it is heated to a temperature $5^{\circ} \mathrm{C}$ lower than the operating temperature.

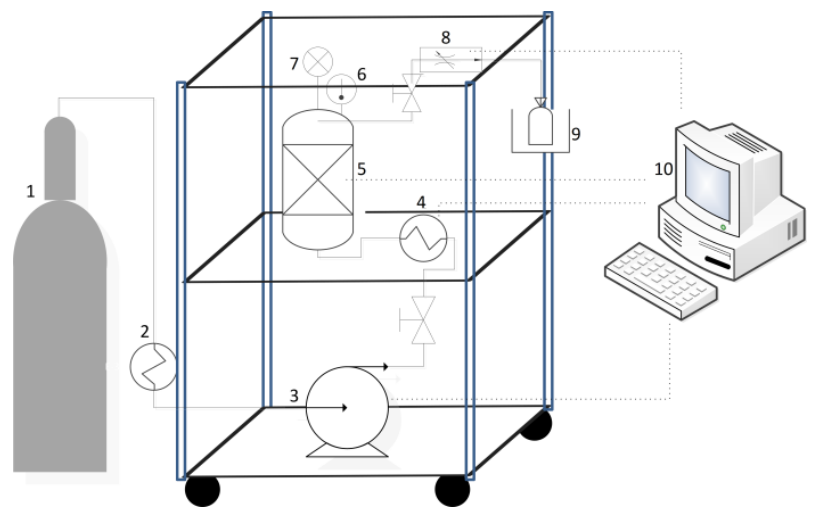

Figure 1. Schematic design (drawing) of the supercritical extractor (Thar Technologies Inc.). In highlighted, the $\mathrm{CO}_{2}$ cylinder (1), heat exchanger (2), HPLC pump (3), heat exchanger (2), fixed-bed extraction (4) with, manometer (5) and thermocouple (6) attached, pressure controller (7), the oil-collecting flask in an ice bath (8), and computer with integrated software equipment (9)

Then, the $\mathrm{CO}_{2}$ reaches the jacketed extractor (5) with a temperature (6) and pressure (7) control. The extracted oil with $\mathrm{CO}_{2}$ passes through a pressure regulator (8) and is recovered in a penicillin flask in an ice bath (9). The pump, heat exchangers, pressure regulator, and extractor heat are controlled via software (10, Thar Technologies Inc., Suite SuperChrom SFC v. 5.9, USA).

The operational conditions were chosen considering that fish oil is thermally degradable [17] and that Rubio-Rodríguez et al. [14] showed that higher yields of oil from fish by-products were achieved at 250 bar and $40^{\circ} \mathrm{C}$. So, in this case, the CLO supercritical extraction was carried out at 250 bar, and the effect of different temperatures on the extraction yield was studied at 50,60, and $70^{\circ} \mathrm{C}$. To check the influence of $\mathrm{CO}_{2}$ flow rate in the oil yield, experiments were also carried out at 250 bar and $50^{\circ} \mathrm{C}$ and $60^{\circ} \mathrm{C}$, but using flow rates of 5,8 , and $11 \mathrm{~g} \mathrm{CO}_{2} /$ min (Table 1). All extractions were carried out within $6 \mathrm{~h}$, without static time, and in triplicate.

Table 1. Study of the operating conditions of the supercritical extraction from cobia liver oil

\begin{tabular}{ccc}
\hline \multicolumn{3}{c}{ First stage of study of operating conditions } \\
\hline FR $\left(\mathrm{g} \mathrm{CO}_{2} / \mathrm{min}\right)$ & $\mathrm{T}\left({ }^{\circ} \mathrm{C}\right)$ & $\mathrm{CLO}(\%)$ \\
\hline & 50 & $57.7 \pm 2.6^{\mathrm{a}}$ \\
8 & 60 & $54.3 \pm 0.9^{\mathrm{ab}}$ \\
& 70 & $49.1 \pm 0.7^{\mathrm{b}}$ \\
\hline \multicolumn{3}{c}{ Second stage of study of operating conditions } \\
\hline FR $\left(\mathrm{g} \mathrm{CO}_{2} / \mathrm{min}\right)$ & $\mathrm{CLO}-50^{\circ} \mathrm{C}(\%)$ & $\mathrm{CLO}-60^{\circ} \mathrm{C}(\%)$ \\
\hline 5 & $39.9 \pm 6.2^{\mathrm{a}}$ & $44.5 \pm 0.2^{\mathrm{b}}$ \\
8 & $57.7 \pm 1.9^{\mathrm{a}}$ & $54.3 \pm 0.9^{\mathrm{a}}$ \\
11 & $43.7 \pm 0.6^{\mathrm{a}}$ & $51.9 \pm 2.8^{\mathrm{a}}$ \\
\hline
\end{tabular}

Mean \pm standard deviation. FR - Flow rate. $-\mathrm{T}$ - temperature.

Oil yields followed by the same letters are not statistically different at $95 \%$ significance by the Tukey test.

\subsection{Physico-Chemical Characterisation of CLO}

Cobia liver samples before and after the supercritical extraction were analysed by scanning electron microscope (Hitachi, TM 3000, Tokyo, JP) for morphological analysis. Sample viscera were fixed with carbon double-sided adhesive in aluminium support, and micrographs were generated with an accelerated voltage of $5 \mathrm{kV}$.

The refractive index (RI), acidity index (AI), peroxide value (PV), iodine value (IV), and saponification number (SN) were quantified in CLO samples according to standardised analytical methods of IAL [16]. The RI was measured in a refractometer (LAMBDA 2WAJ, ATTO Instruments $\mathrm{Co}$, Tsuen Wan, $\mathrm{HK}$ ) at 25 and $40{ }^{\circ} \mathrm{C}$ (Zenebon et al. 2008).

To determine the AI, we used the titration method, with a standardised solution of sodium hydroxide (Haloquímica, São Paulo, BR) $0.01 \mathrm{M}$ and phenolphthalein as an indicator (Synth, São Paulo, BR). In the PV analysis, CLO was mixed with a solution of acetic acid (Synth Sao Paulo, BR): chloroform (Êxodo, Sao Paulo, BR) (3:2) and a saturated solution of potassium iodide (Synth Sao Paulo, BR). Titration of this solution mixed with distilled water with 0.1 M of sodium thiosulfate (Haloquímica, São Paulo, BR) was made using $0.5 \mathrm{~mL}$ of $1 \%$ starch (Haloquímica, São Paulo, $\mathrm{BR}$ ) as a turning-point indicator. In this analysis, a sample with no treatment was titrated and used as a blank.

In determining the IV, CLO samples were mixed with cyclohexane (Synth, São Paulo, BR) and Wijs solution (Haloquímica, São Paulo, BR), and after $30 \mathrm{~min}$, potassium iodide $(15 \%)$ and distilled water were added. The titration was performed with a standardised sodium thiosulfate solution, using starch as an indicator. A blank solution without oil was titrated under the same conditions. The SN 
was determined by adding an alcoholic solution of potassium hydroxide (4\%) (Exodus, São Paulo, BR) to the $\mathrm{CLO}$, and this solution was then heated for $30 \mathrm{~min}$. The mixture was titrated with a standardised solution of hydrochloric acid (Haloquímica, São Paulo, BR), using phenolphthalein as an indicator. A control solution without oil was made and titrated under the same conditions.

\subsection{Fatty Acids Profile and Squalene Quantification}

The fatty acids profile was performed according to the method 991.39, AOAC [18], with modifications. In a Falcon tube containing $50 \mathrm{mg}$ sample of CLO, $4 \mathrm{~mL}$ of $\mathrm{NaOH}$ solution in methanol (Synth, Diadema, BR) $0.5 \mathrm{M}$ was added, and the mixture was heated at $100^{\circ} \mathrm{C}$ in a water bath for $5 \mathrm{~min}$. Then, $5 \mathrm{~mL}$ of methanolic solution of $\mathrm{BF}_{3}$ (Sigma-Aldrich, Saint Louis, USA) was added and heated for $30 \mathrm{~min}$. Subsequently, $4 \mathrm{~mL}$ of saline solution and $5 \mathrm{~mL}$ of hexane (Merck, Darmstadt, DE) were added, and the mixture was placed under stirring for $1 \mathrm{~min}$. After phase separation, the light phase, containing the methyl esters of fatty acids, was transferred to a flask and dried. The mass of methyl ester fatty acids was dissolved in hexane at a known concentration and transferred to a vial.

The fatty acids analysis was performed by gas chromatography coupled with mass spectrometry, GC/MS (QP 2010 Plus, Shimadzu, Tokyo, JP) with an automatic injector (AOC-5000, Shimadzu, Tokyo, JP), according to the method 996.06, AOAC [18], with modifications. In this analysis, we used a capillary column with stationary phase poly (biscyanopropyl siloxane) $(100 \mathrm{~m} \times 0.25 \mathrm{~mm}$ id $\times 0.20$ $\mu \mathrm{m}$ df, SP-2560) (Supelco, Bellefonte, USA), gas helium as a carrier gas to an internal speed of $19.5 \mathrm{~cm} / \mathrm{s}$. It was injected $1.0 \mu \mathrm{L}$ of the solution containing methyl esters in hexane in the splitless mode. The injector temperature was $250^{\circ} \mathrm{C}$, and the detector was $260^{\circ} \mathrm{C}$. The oven temperature was regulated to obtain a ramp starting at $100^{\circ} \mathrm{C}$ for $1 \mathrm{~min}$, $100^{\circ} \mathrm{C}$ to $195^{\circ} \mathrm{C}$ at a rate of $5^{\circ} \mathrm{C} / \mathrm{min}$, and then $195^{\circ} \mathrm{C}$ to $250^{\circ} \mathrm{C}$. The previous identification of the peaks was made by comparison of the mass spectra from the NIST library and NIST 08S, and the quantification was performed by external standardisation relating the peak area with the standard curve of myristic acid methyl ester (Sigma-Aldrich, Saint Louis, USA).

Squalene quantification was performed according to $\mathrm{Lu}$ et al. [19]. In a Falcon tube containing $0.5 \mathrm{~g}$ of CLO, $40 \mathrm{~mL}$ of a mixture of methanol: acetone $(7: 3, \mathrm{v} / \mathrm{v})$ was added. The mixture was homogenised for $5 \mathrm{~min}$ in a mechanical shaker (vortex) and stored at $-2^{\circ} \mathrm{C}$ for $30 \mathrm{~h}$. The supernatant was quickly filtered through a $0.45 \mathrm{~mm}$ membrane (Whaltman, Kent, UK). The residue was washed with $5 \mathrm{~mL}$ of a cooled solution of methanol: acetone $(7: 3, \mathrm{v} / \mathrm{v})$ at $-20^{\circ} \mathrm{C}$. The filtrate was dried in a vial and stored under refrigeration. At the injection into GC/MS (QP 2010 Plus, Shimadzu, JP), the filtrate was resuspended in $5 \mathrm{~mL}$ of acetone.

The chromatographic analysis was performed according to Brunner et al. [20], with modifications. It was used as stationary phase column RTX-5MS (5\% diphenyl/95\% dimethyl polysiloxane) $(30 \mathrm{~m} \times 0.25 \mathrm{~mm}$ id $\times 0.20 \mu \mathrm{m} \mathrm{df}$ Restek, Bellefonte, USA), helium as carrier gas to an internal speed of $19.5 \mathrm{~cm} / \mathrm{s}$. The solution of squalene in acetone $(1.0 \mu \mathrm{L})$ was injected in splitless mode. The temperatures of the injector, detector, and interface were $280^{\circ} \mathrm{C}, 300^{\circ} \mathrm{C}$, and $300^{\circ} \mathrm{C}$, respectively. The oven temperature was regulated to obtain a ramp starting at $130^{\circ} \mathrm{C}$ for $2 \mathrm{~min}, 130^{\circ} \mathrm{C}$ to $200^{\circ} \mathrm{C}$ at a rate of $10^{\circ} \mathrm{C} / \mathrm{min}$, from $200^{\circ} \mathrm{C}$ to $290^{\circ} \mathrm{C}$ at $5^{\circ} \mathrm{C} / \mathrm{min}$ and remaining at $290^{\circ} \mathrm{C}$ for $15 \mathrm{~min}$. The previous identification of the peaks was made by comparison of the mass spectra with those from NIST and 08S NIST library and by comparing the retention time with the standard. The external standardisation was applied in the squalene quantification, relating the peak area of the samples with the standard squalene curve (Santa Cruz, Dallas, USA).

The means of the results of physico-chemical analysis and squalene contents were evaluated statistically by ANOVA, and means differences were tested by Tukey's test, for $95 \%$ of significance level.

\section{Results and Discussion}

\subsection{Cobia Liver Characterisation and Extraction Yield}

Cobia liver is a rich source of lipids, which comprise over $65 \%$ of the total. It also presents a significant amount of protein (Table 2). The lyophilisation process reduced water content and provided lipids (macromolecular group most abundant in the viscera after water) for extraction.

Table 2. Chemical composition of cobia livers

\begin{tabular}{cc}
\hline Components & Cobia liver \\
\hline Moisture & $4.94 \pm 0.05$ \\
Ash & $2.1 \pm 0.0$ \\
Proteins & $21.67 \pm 0.13$ \\
Fibers & $0.3 \pm 0.1$ \\
Lipids & $65.98 \pm 0.83$ \\
Carbohydrates & $5.03 \pm 0.87$ \\
\hline
\end{tabular}

Mean \pm standard deviation. All measurements are expressed in $\mathrm{g} x$ 100-1 g of sample.

Proteins correspond to the second macromolecular group present in the lyophilised liver cobia, 21\%. Supercritical $\mathrm{CO}_{2}$ does not solubilise the protein, so a protein-free lipid residue after extraction can be utilised as a source of proteins for application as animal feed formulation, for example. This application should be studied as well as cobia liver composition in amino acids, which could extend its use to more specific purposes. Chalamaiah et al. [21] reported that various biotechnological processes are currently used to recover the peptides, which present an important physiological and nutritional character, such as enzymatic hydrolysis of fish protein, which results in the production of 
biologically active protein hydrolysates. Studies of protein hydrolysis of liver free from lipid material and without contaminant can be an example of application for this raw material.

The variation of the material structure before and after the supercritical fluid extraction is another important experimental observation for CLO extraction. In micrographs, pores produced by the water removal during lyophilisation were evident (Figure 2a). After extraction, the material presented a non-uniform appearance (Figure $2 b$ ), in which several fissures formed after supercritical $\mathrm{CO}_{2}$ contact during the extraction, similar to extruded material.

The supercritical fluid extraction of CLO under different conditions provided different results. Table 1 shows the average oil yield for the three temperatures $\left(50,60\right.$, and $\left.70^{\circ} \mathrm{C}\right)$ used in the process at the same pressure (250 bar). Specifically, at 50 and $60^{\circ} \mathrm{C}$, the yield of the CLO was studied for different $\mathrm{CO}_{2}$ flow rates: 5, 8, and $11 \mathrm{~g} \mathrm{CO}_{2} / \mathrm{min}$.

The highest yields of CLO were obtained at temperatures between 50 and $60^{\circ} \mathrm{C}$ - conditions of higher solvent density. The solubility of solutes in supercritical fluids is influenced by temperature and pressure, which interfere in the solvent density. Increasing the temperature increases the solute vapour pressure, which facilitates its solubilisation and, at the same time, decreases the solvent density $\left(\rho \mathrm{CO}_{2}-50^{\circ} \mathrm{C}=\right.$ $834.62 \mathrm{~kg} / \mathrm{m}^{3}, \rho \mathrm{CO}_{2}-60^{\circ} \mathrm{C}=786.99 \mathrm{~kg} / \mathrm{m}^{3}, \rho \mathrm{CO}_{2}-70^{\circ} \mathrm{C}=$ $738.02 \mathrm{~kg} / \mathrm{m}^{3}$ ). A lower density may cause a lower solvency power, negatively influencing the solubility of the solute in the system $[22,23]$.

Conditions of $\mathrm{P}$ and $\mathrm{T}$ which provided higher yield were used to study the influence of the $\mathrm{CO}_{2}$ flow rate in CLO extraction. Higher absolute yields were obtained at a rate of 8 and $11 \mathrm{~g} \mathrm{CO}_{2} / \mathrm{min}$, presenting no significant difference by Tukey's test. However, considering the economy of the process extraction, the flow rate of $8 \mathrm{~g} \mathrm{CO}_{2} / \mathrm{min}$ could be considered the more efficient.

Rai et al. [24] summarised the supercritical fluid extraction process in the following steps: $(i)$ the contact of the supercritical solvent with the particle surface, and then from the particle surface to inside of the particles by diffusion; ( $i$ i) the dissolution of the solute in the supercritical solvent; (iii) the transport of the molecules dissolved in supercritical solvent from the particle interior to the particle surface; and (iv) the migration of the supercritical solvent with the solute from the particles' surface to the supercritical phase.

Cobia liver presented as a porous material that facilitates the diffusion of the $\mathrm{CO}_{2}$. Although not all of the oil content was extracted $(\approx 66 \%)$ (Table 2$)$, the extraction yields obtained may still be considered high (from $\approx 49$ to $\approx 58 \%$ ) (Table 1). Further, it should be taken into account some advantages of supercritical $\mathrm{CO}_{2}$ extraction, as a process that does not use organic solvents and is performed with low temperatures compared to conventional processes.
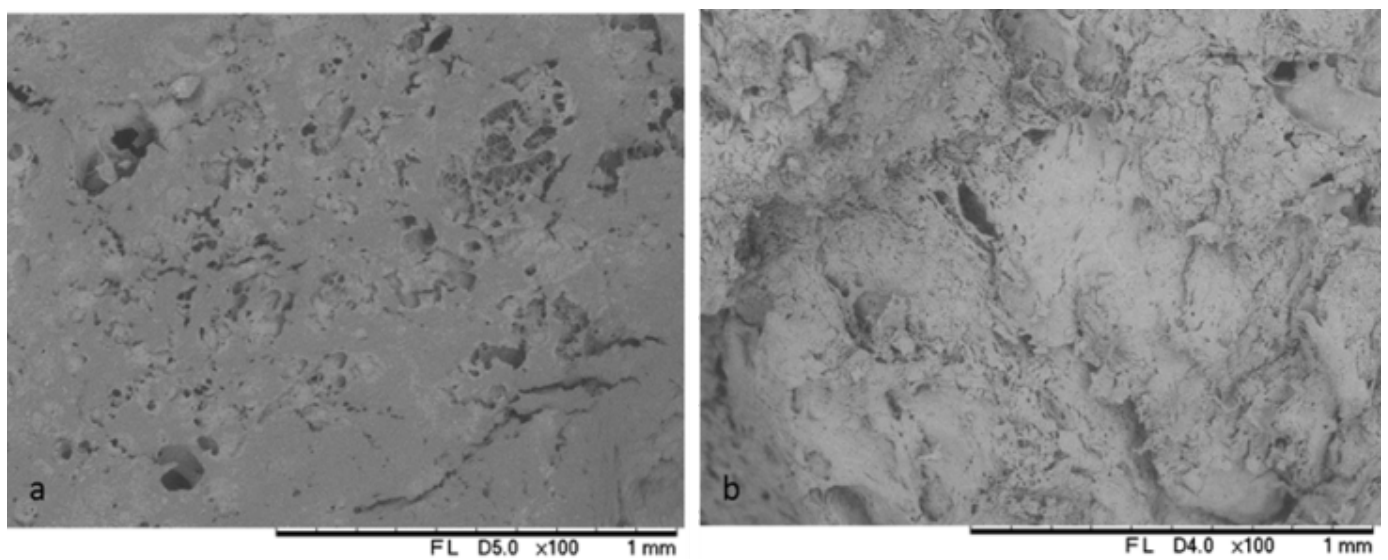

Figure 2. Scanning electron microscopy of freeze-dried cobia liver before the supercritical extraction of oil (A) and after extraction to 250 bar, $8 \mathrm{~g} \mathrm{CO} /$ $\min , 60^{\circ} \mathrm{C}(\mathrm{B})$

Table 3. Physico-chemical characterisation of cobia liver oil

\begin{tabular}{ccccccc}
\hline $\mathrm{CLO}$ & $\mathrm{RI}\left(25^{\circ} \mathrm{C}\right)$ & $\mathrm{RI}\left(40^{\circ} \mathrm{C}\right)$ & $\mathrm{AI}^{*}$ & $\mathrm{OI}^{* *}$ & $\mathrm{SI}^{* * *}$ & $\mathrm{PI}^{* * * *}$ \\
\hline $50^{\circ} \mathrm{C}$ & $1.469^{\mathrm{a}} \pm 0$ & $1.466^{\mathrm{a}} \pm 0$ & $13.63 \pm 0.22^{\mathrm{b}}$ & $68.92 \pm 6.34^{\mathrm{b}}$ & $195.50 \pm 15.37^{\mathrm{a}}$ & - \\
$60^{\circ} \mathrm{C}$ & $1.471^{\mathrm{a}} \pm 0$ & $1.466^{\mathrm{a}} \pm 0$ & $14.8 \pm 1.5^{\mathrm{ab}}$ & $66 \pm 5^{\mathrm{b}}$ & $196.57 \pm 8.35^{\mathrm{a}}$ & - \\
$70^{\circ} \mathrm{C}$ & $1.470^{\mathrm{a}} \pm 0$ & $1.466^{\mathrm{a}} \pm 0$ & $16.94 \pm 1.92^{\mathrm{a}}$ & $79.02 \pm 0.71^{\mathrm{a}}$ & $186.19 \pm 4.72^{\mathrm{a}}$ & - \\
\hline
\end{tabular}

Mean \pm standard deviation. Physico-chemical parameters of oils followed by the same letters in the same column do not differ statistically at $95 \%$ significance by the Tukey test. RI - refractive index.

* Acid value expressed as \% oleic acid.

** Iodine value in $\mathrm{g} \mathrm{I}_{2} / 100 \mathrm{~g}$ of oil.

*** Saponification value expressed as meq $/ \mathrm{kg}$ oil.

$* * * *$ Peroxide value expressed in active $\mathrm{Meq}_{2} / \mathrm{kg}$ oil. 


\subsection{Cobia Liver Oil}

RI values at 25 and $40^{\circ} \mathrm{C}$ did not vary $(\mathrm{p}<0.05)$ when different temperatures were used in the extraction (Table 3 ). These RIs are similar to other fish oils, such as the crude oil from Oreochromis niloticus and Pseudoplatystoma corruscans $\times$ P. fasciatum [25]. According to a study by Immanuel et al. [26], oil from Sufflamen capistratus liver obtained by different extraction methods showed no significant differences in the RI. The authors explained that the refraction angles are defined as a function of the fat composition, and a variation in these values could indicate that it was made a mix of different oils. RI is an index that indicates the quality standard of oils and fats.

The acidity value of CLO ranged from 13.63 to $16.94 \%$, showing that increasing the temperature in the extraction positively influenced the oleic acid percentage in the oil (Table 3). This percentage is high compared with other fish oils [25, 27] and even for values recommended by the European Food Safety Authority [28], from 1 to 7\%. The IV (Table 3) is lower than those other oils. For example, Araújo et al. [29] found mean values of $119.23 \mathrm{~g} \mathrm{I}_{2} / 100 \mathrm{~g}$ fish oil. These results showed a good physico-chemical quality of $\mathrm{CLO}$ obtained by supercritical $\mathrm{CO}_{2}$ extraction. However, it was observed that for higher temperature in the process, the iodine content increases significantly (Table 3 ).

The SN ranged from 186.19 to $196.57 \mathrm{meq} / \mathrm{Kg}$ CLO, and there was no significant difference between the oil obtained at different temperatures in the process (Table 3). These values are similar to those found for other fishes [25], and this parameter is indicative of fresh fish oil. The PVs determined for CLO obtained at different temperatures were lower than 0.2 meq of active $\mathrm{O}_{2} / \mathrm{kg}$ (Table 3). These values were lower than those recommended by the EFSA [28], ranging from 3 to 20 meq active $\mathrm{O}_{2} / \mathrm{kg}$ for raw fish oils.

Table 4. Fatty acids profile (g/100g CLO) and squalene content in cobia liver oil

\begin{tabular}{|c|c|c|c|c|c|}
\hline TR (min) & AG & Name & $\mathrm{CLO}\left(50^{\circ} \mathrm{C}\right)$ & $\mathrm{CLO}\left(60^{\circ} \mathrm{C}\right)$ & $\mathrm{CLO}\left(70^{\circ} \mathrm{C}\right)$ \\
\hline 20.81 & $14: 0$ & Myristic acid & 2.47 & 1.95 & 2.2 \\
\hline 22.32 & $15: 0$ & Pentadecanoic acid & 0 & 0 & 0.35 \\
\hline 23.93 & $16: 0$ & Palmitic acid & 18.85 & 16.9 & 19.83 \\
\hline 25.40 & $17: 0$ & Margaric acid & 0.48 & 0.38 & 0 \\
\hline \multirow[t]{2}{*}{27.07} & 18:0 & Stearic acid & 8.34 & 7.39 & 8.4 \\
\hline & & $\sum \mathrm{SFA}^{\mathrm{a}}$ & 30.14 & 26.62 & 30.78 \\
\hline 24.85 & $16: 1 n-7$ & Methyl hexadec-9-enoate acid & 1.37 & 1.14 & 1.18 \\
\hline 25.02 & $16: 1 n-7$ & Palmitoleic acid & 6.86 & 5.84 & 7.22 \\
\hline 26.51 & $17: 1 n-9$ & Margaroleic acid & 0.76 & 0.66 & 0.67 \\
\hline 28.23 & $18: 1 n-9$ & Oleic acid & 29.11 & 27.93 & 32.81 \\
\hline 28.32 & $18: 1 n-9 t$ & Elaidic acid & 4.27 & 3.95 & 5.3 \\
\hline \multirow[t]{2}{*}{31.54} & $20: 1 n-9$ & cis-11-eicosenoic acid & 1.94 & 1.7 & 1.8 \\
\hline & & $\sum$ MUFA $^{\mathrm{b}}$ & 44.31 & 41.22 & 48.98 \\
\hline 29.42 & $18: 2 n-6 t$ & 6,9(E,E)-octadecadienoic acid & 1.11 & 0.94 & 1.02 \\
\hline 29.84 & $18: 2 n-6$ & Linoleic acid & 10.93 & 10.25 & 12.71 \\
\hline 31.10 & $18: 3 n-6$ & $\gamma$-linolenic acid & 1.15 & 1.02 & 1.13 \\
\hline 33.36 & $20: 2 n-6$ & Eicosadienoic acid & 1.08 & 1.01 & 1.00 \\
\hline 35.89 & $20: 4 n-6$ & Arachidonic acid & 1.44 & 1.32 & 1.43 \\
\hline \multirow[t]{2}{*}{34.77} & $20: 3 n-6$ & 7,10,13-eicosatrienoic acid & 0.61 & 0.56 & 0.52 \\
\hline & & $\sum \omega-6$ PUFA $^{\mathrm{c}}$ & 16.32 & 15.1 & 17.81 \\
\hline 31.83 & $18: 3 n-3$ & $\alpha$-linolenic acid & 1.65 & 1.48 & 1.73 \\
\hline 38.29 & $20: 5 n-3$ & eicosapentaenoic acid & 1.6 & 1.55 & 1.72 \\
\hline 42.57 & $22: 5 n-3$ & docosapentaenoic acid & 1.23 & 1.26 & 1.25 \\
\hline \multirow[t]{4}{*}{43.68} & $22: 6 n-3$ & docosahexaenoic acid & 2.43 & 2.43 & 2.82 \\
\hline & & $\sum \omega-3$ PUFA $^{\mathrm{d}}$ & 6.91 & 6.72 & 7.52 \\
\hline & & $\sum$ PUFA $^{\mathrm{e}}$ & 23.23 & 21.82 & 25.33 \\
\hline & \multicolumn{2}{|c|}{ Squalene (mg/ 100g CLO) } & $354.2 \pm 2.2^{\mathrm{C}}$ & $417,15 \pm 13.43^{\mathrm{B}}$ & $461.7 \pm 11.5^{\mathrm{A}}$ \\
\hline
\end{tabular}

atotal saturated fatty acids

b total monounsaturated fatty acids

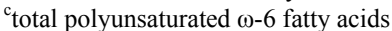

$\mathrm{d}_{\text {total }}$ polyunsaturated $\omega-3$ fatty acids

${ }^{e}$ total polyunsaturated fatty acids 
The main fatty acids found in CLO (Table 4) were oleic, palmitic, and linoleic acids. Saturated fatty acid amounts were from 26 to $31 \mathrm{~g} / 100 \mathrm{~g}$ CLO. Monounsaturated fatty acids were the majority class, with values from 41 to 49 $\mathrm{g} / 100 \mathrm{~g}$ CLO. The fatty acids proportion in the CLO was the same regardless of the temperature used in the supercritical $\mathrm{CO}_{2}$ extraction process; however, the absolute contents of the fatty acids in the oil obtained at $60^{\circ} \mathrm{C}$ was lower than the CLO obtained at 50 and $70^{\circ} \mathrm{C}$.

In the supercritical extraction of polyunsaturated fatty acids (PUFA) from Cyprinus carpio L. viscera, was checked the influence of the extraction parameters in the production of PUFAs. Higher pressure presented a positive influence on the yield of PUFA, and the temperature, in low pressure conditions, provides decreasing in the PUFA yield [30].

Similar levels of MUFA were found in the liver oil from cobia fed with two different diets. However, high differences occurred in the amounts of MUFA and PUFA. MUFA content represented $27.0 \%$ of the fatty acids (fed fish) and $22.4 \%$ (fed soy-based feed), which was lower than CLO from $\mathrm{CO}_{2}$ supercritical extraction (Table 4). PUFA showed higher values, $46.9 \%$ (fed fish) and $56.6 \%$ for (fed soy-based feed) [31].

Saturated fatty acids from CLO (Table 4) are lower than from Oreochromis niloticus and Pseudoplatystoma corruscans $\times P$. fasciatum oil [25]. However, for MUFA, the CLO contents are more expressive.

PUFAs, especially EPA and DHA, present numerous biochemical and pharmacological effects on human health in the treatment or prevention of certain diseases [32]. The fatty acids $\omega-3$ are essential for normal human growth and development, and it is important for the prevention and treatment of coronary artery disease, hypertension, arthritis, other inflammatory and autoimmune diseases, and cancer [33].

Different contents of squalene (Table 4) $(\mathrm{p}<0.05)$ were obtained. The highest value was found in the CLO extracted at $70^{\circ} \mathrm{C}$, which may be indicative of the positive influence of temperature on the vapour pressure of the solute, which facilitates extraction. Results of supercritical extraction of squalene from amaranth seed showed that high temperatures and low pressures provided higher squalene [34].

Squalene is a compound whose main animal source is shark [35]. Squalene composes up to $79 \%$ of animals of the Squalidae family [36]. In shark oil obtained by conventional methods of extraction such as Soxhlet and Bligh-Dyer, squalene contents ranged from 28 to $40 \mathrm{mg} / 100 \mathrm{~g}$ oil [37], which is lower than squalene in CLO (Table 4).

The biological importance of squalene is varied, and it can act enhancing effects of the immune system [38], blocking singlet oxygen in biological systems, and presents chimoprotective effects against cancer [39, 40]. Considering these active properties and the scarcity of the shark species in which squalene is common, other sources have been studied, such as amaranth [34] and olive oil [41]. In this context, the results found for oil from cobia liver, a waste product of the fish processing industry, would classify as a potential source for the generation of oil rich in squalene. Supercritical $\mathrm{CO}_{2}$ extraction promotes the oil enrichment in squalene as an advantage to conventional processes, since it is possible to have more squalene in the oil by a simple modification of the process variables ( $\mathrm{P}$ and $\mathrm{T})$. Moreover, $\mathrm{CO}_{2}$ is an inorganic solvent which exists in a gaseous state at room temperature, and it leaves no residue in the oil.

\section{Conclusions}

This original research is important for the fish chain, including cultivation and processing, since this study shows a possibility to increase the CLO production as a by-product with active properties. The data showed here insert the cobia liver in the class of the great producers matrices of fish oil rich in squalene. CLO extracted with supercritical $\mathrm{CO}_{2}$ is an oil with physico-chemical characteristics similar to other fish oils marketed with a fatty acid profile showing high levels of MUFA and large amounts of omega 3. CLO also showed a high content of squalene, an important bioactive compound, which encourages the application of this oil not only in the food industry but also in the pharmaceutical industry.

\section{ACKNOWLEDGEMENTS}

The authors would like to thank FAPESP (São Paulo Research Foundation, Brazil) for the financial support under the research projects 2012/00467-3 and for the scholarship for the doctoral student. The authors would also like to thank Dr Sheyla Vargas, who donated the cobia liver, and Terroni Company (São Carlos, Brazil), which lyophilised the liver samples.

\section{REFERENCES}

[1] Chuang, W.-H., Liu, P.-C., Hung, C.-Y., Lee, K.-K., 2014, Purification, characterization and molecular cloning of alpha-2-macroglobulin in cobia, Rachycentron canadum, Fish \& Shellfish Immunology, 41, 346-355.

[2] Sun, L., and Chen, H., 2014, Effects of water temperature and fish size on growth and bioenergetics of cobia (Rachycentron canadum), Aquaculture, 426-427, 172-180.

[3] Geng, X., Dong, X.-H., Tan, B.-P., Yang, Q.-H., Chi, S.-Y., Liu, H-Y., Liu, X.-Q., 2011, Effects of dietary chitosan and Bacillus subtilis on the growth performance, non-specific immunity and disease resistance of cobia, Rachycentron canadum, Fish \& Shellfish Immunology, 31, 400-406.

[4] Cavalli, R. O., Domingues, E. C., Hamilton, S., 2011, Desenvolvimento da produção de peixes em mar aberto no Brasil: possibilidades e desafios, R. Bras. Zootec., 40, 155-164.

[5] Food and Agriculture Organization of the United Nations [FAO] (2014). The State of World Fisheries and Aquiculture: Opportunities and challenges. [Online]. Available: 
http://www.fao.org/fishery/sofia/en

[6] Adeoti, I. A., and Hawboldt, K., 2014, A review of lipid extraction from fish processing by-product for use as a biofuel, Biomass and Bioenergy, 63, 330-340.

[7] Jayasinghe, P. and Hawboldt, K., 2012, A review of bio-oils from waste biomass: Focus on fish processing waste, Renewable and Sustainable Energy Reviews, 16, 798-821.

[8] Amiguet, V. T., Kramp, K. L., Mao, J., McRae, C., Goulah, A., Kimpe, L. E., Blais, J. M., Arnason, J. T., 2012, Supercritical carbon dioxide extraction of polyunsaturated fatty acids from Northern shrimp (Pandalus borealis Kreyer) processing by-products, Food Chemistry, 130, 853-858.

[9] Rubio-Rodríguez, N., Diego, S. M., Beltrán, S., Jaime, I., Sanz, M. T., Rovira, J., 2012, Supercritical fluid extraction of fish oil from fish by-products: A comparison with other extraction methods, Journal of Food Engineering, 109, 238-248.

[10] Staby, A. and Mollerup, J., 1993, Separation of constituents of fish oil using supercritical fluids: a review of experimental solubility, extraction, and chromatographic data, Fluid Phase Equilibria, 91, 349-386.

[11] Nilsson, W. B., Gauglitz Jr., E. J., Hudson, J. K., Stout, V. F., Spinelli, J., 1988, Fractionation of menhaden oil ethyl esters using supercritical fluid $\mathrm{CO}_{2}$, JAOCS, 65(1), 109-117.

[12] Higashidate, S., Yamauchi, Y., Saito, M., 1990, Enrichment of eicosapentaenoic acid and docosahexaenoic acid esters from esterified fish oil by programmed extraction-elution with supercritical carbon dioxide, Journal of Chromatography, 515, 295-303.

[13] Krukonis.V. J., 1989, Supercritical fluid processing of fish oils: extraction of polychlorinated biphenyls, JAOCS, 66(6), 818-821.

[14] Rubio-Rodríguez, N., Diego, S. M., Beltrán, S., Jaime, I., Sanz, M. T., \& Rovira, J. (2008). Supercritical fluid extraction of the omega-3 rich oil contained in hake (Merluccius capensis-Merluccius paradoxus) by-products: Study of the influence of process parameters on the extraction yield and oil quality, Journal of Supercritical Fluids, 407, 215-226.

[15] Tenllado, D., Reglero, G., Torres, C. F., 2011, A combined procedure of supercritical fluid extraction and molecular distillation for the purification of alkylglycerols from shark liver oil, Separation and Purification Technology, 83, 74-81.

[16] Zenebon, O., Pascuet, N. S., Tiglea, P. (coord.), 2008, Instituto Adolfo Lutz (São Paulo). Métodos físico-químicos para análise de alimentos 4 ed, 1th digital edition. São Paulo, 1020 p.

[17] Davarnejad, R., Kassim, K. M., Zainal, A., Sata, S. A., 2009, Extraction of fish oil by fractionation through supercritical carbon dioxide, Journal of Chemical \& Engineering Data, 53(9), 2128-2132.

[18] AOAC. Official Methods of Analysis of AOAC International, 2005, 18th Ed., AOAC International, Gaithersburg, MD, USA, Official Methods 966.06 and 991.39.

[19] Lu, H.-T., Jiang, Y., Chen, F., 2003, Preparative separation and purification of squalene from the microalga Thraustochytrium ATCC 26185 by high-speed counter-current chromatography, Journal of Chromatography A, 994, 37-43.

[20] Brunner, G., Saura, C., Buss, D., 2009, Phase equilibrium of hydrogen, carbon dioxide, squalene, and squalene, J. Chem. Eng. Data, 54, 1598-1609.

[21] Chalamaiah, M., Kumar, B. D., Hemalatha, R., Jyothirmayi, T., 2012, Fish protein hydrolysates: Proximate composition, amino acid composition, antioxidant activities and applications: A review, Food Chemistry, 135(4), 3020-3038.

[22] Brunner, G., 2005, Supercritical fluids: technology and application to food processing, Journal of Food Engineering, 67, 21-33.

[23] Moura, P. M., Prado, G. H. C., Meireles, M. A. A., Pereira, C. G., 2012, Supercritical fluid extraction from guava (Psidium guajava) leaves: Global yield composition and kinetic data, Journal of Supercritical Fluids, 62, 116-122.

[24] Rai, A. Punase, K. D., Mohanty B., Bhargava, R., 2014, Evaluation of models for supercritical fluid extraction, International Journal of Heat and Mass Transfer, 72, 274-287.

[25] Menegazzo, M. L., Petenuci, M. E., Fonseca, G. G., 2014, Production and characterization of crude and refined oils obtained from the co-products of Nile tilapia and hybrid sorubim processing, Food Chemistry, 157, 100-104.

[26] Immanuel, G., Sathasivan, S., Shankar, V. S., Peter, M. J. P., Palavesam, A., 2009, Processing and characterisation of low cost Balistid fish Sufflamen capistratus liver oil for edible purpose, Food Chemistry, 115, 430-435.

[27] Selmi, S., Limam, Z., Batista, I., Bandarra, N. M., Nunes, M. L., 2011, Effects of storage temperature and $\alpha$-tocopherol on oil recovered from sardine mince, International Journal of Refrigeration, 34, 1315-1322.

[28] European Food Safety Authority (ESFA), 2010, Scientific Opinion on Fish Oil for Human Comsumption. Food Hygiene, including Rancidity. Panel on Biological Hazards (BIOHAZ). EFSA Journal, 8(10), 1874-1922.

[29] Araújo, K. L. G. V., Epaminondas, P. S., Silva, M. D. C., Lima, A. E. .A., Rosenhaim, R., Maia, A. S., Soledade, L. E. B., 2011, Influence of thermal degradation in the physicochemical properties of fish oil, J Therm Anal Calorim, 106, 557-561.

[30] Kuvendziev, S., Lisichkova, K., Zeković, Z., Marinkovski, M., 2014, Artificial neural network modelling of supercritical fluid $\mathrm{CO}_{2}$ extraction of polyunsaturated fatty acids from common carp (Cyprinus carpio L.) viscera, Journal of Supercritical Fluids, 92, 242-248.

[31] Trushenski, J., Schwarz, M., Bergman, A., Rombenso, A., Delbos, B., 2012, DHA is essential, EPA appears largely expendable, in meeting the $n-3$ long-chain polyunsaturated fatty acid requirements of juvenile cobia Rachycentron canadum, Aquaculture, 326-329, 81-89.

[32] Wang, W., Li, T., Ning, Z., Wang, Y., Yang, B., Ma Y., Yang, X., 2012, A process for the synthesis of PUFA-enriched triglycerides from high-acid crude fish oil, Journal of Food Engineering, 109, 366-371.

[33] Corrêa, A. P. A., Peixoto, C. A., Gonçalves, L. A. G., Cabral, F. A., 2008, Fractionation of fish oil with supercritical carbon dioxide, Journal of Food Engineering, 88, 381-387. 
[34] Wejnerowska, G., Heinrich, P., Gaca, J., 2013, Separation of squalene and oil from Amaranthus seeds by supercritical carbon dioxide, Separation and Purification Technology, 110, $39-43$.

[35] Navarro-Garcia, G., Pacheco-Aguilar, R., Vallejo-Cordova, B., Ramirez-Suarez, J. C., Bolaños, A., 2000, Lipid Composition of the Liver Oil of Shark Species from the Caribbean and Gulf of California Waters, Journal of Food Composition and Analysis, 13, 791-798.

[36] Wetherbee, B. M., Nichols, P. D., 2000, Lipid composition of the liver oil of deep-sea sharks from the Chatham Rise, New Zealand, Comparative Biochemistry and Physiology Part B, $125,511-521$.

[37] Sunarya, Hole, M., Taylor, K. D. A., 1996, Methods of extraction composition and stability of vitamin A and other components in dogfish (Squalus acanthias) liver oil, Food Chemistry, 55, 215-220.
[38] Lippi, G., Targher, G., Franchini, M., 2010, Vaccination, squalene and anti-squalene antibodies: Facts or fiction?, European Journal of Internal Medicine, 21, 70-73.

[39] Rao, C. V., Newmark, H. L., Reddy, B. S., 1998, Chemopreventive effect of squalene on colon cancer, Carcinogenesis, 19(2), 287-290.

[40] Aguilera, Y., Dorado, M. E., Prada, F. A., Martínez, J. J., Quesada, A., Ruiz-Gutiérrez, V., 2005, The protective role of squalene in alcohol damage in the chick embryo retina, Experimental Eye Research, 80, 535-543.

[41] Nenadis, N., and Tsimidou, M., 2002, Determination of squalene in olive oil using fractional crystallization for sample preparation, JAOCS, 79(3), 257-259. 